\title{
Genetic diversity and temporal variation of the marine Synechococcus community in the subtropical coastal waters of Hong Kong
}

\author{
Hongmei Jing, Rui Zhang, Stephen B. Pointing, Hongbin Liu, and Peiyuan Qian
}

\begin{abstract}
The phylogenetic diversity of the marine Synechococcus community in the subtropical coastal waters of Hong Kong, China, was examined through intergenic transcribed spacer clone libraries. All the sequences obtained fell within both marine cluster A (MC-A) and B (MC-B), with MC-A phylotypes dominating throughout the year. Distinct phylogenetic lineages specific to Hong Kong waters were detected from both MC-A and MC-B. The highest Synechococcus community diversity occurred in December, but the highest Synechococcus abundance occurred in August. On the other hand, both the abundance and diversity of Synechococcus showed a minimum in February. The remarkable seasonal variations of Synechococcus diversity observed were likely the result of the changes of hydrographic condition modulated by monsoons. Principal component analysis revealed that the in situ abiotic water characteristics, especially salinity and water turbidity, explained much of the variability of the marine Synechococcus population diversity in Hong Kong coastal waters. In addition, the temporal changes of Synechococcus abundance were largely driven by water temperature.
\end{abstract}

Key words: Synechococcus, phylogenetic diversity, Hong Kong, 16S-23S rDNA internal transcribed spacer.

Résumé : La diversité phylogénique de la communauté marine de Synechococcus des eaux côtières subtropicales de Hong Kong (Chine) a été examinée à l'aide de banques de clones de la région transcrite de l'espaceur intergénique. Toutes les séquences obtenues se retrouvaient dans les clusters marins A (CM-A) et B (CM-B), les phylotypes CM-A étant dominant au cours de toute l'année. Des lignées phylogéniques distinctes spécifiques aux eaux de Hong Kong étaient présentes dans les deux groupes CM-A et CM-B. La diversité de la communauté de Synechococcus était la plus forte en décembre, mais les bactéries étaient plus abondantes en août. En revanche, l'abondance et la diversité de Synechococcus étaient minimales en février. Ces remarquables variations saisonnières de la diversité de Synechococcus étaient probablement le résultat de changements des conditions hydrographiques modulées par la mousson. L'analyse des principales composantes a révélé que les caractéristiques abiotiques de l'eau in situ, notamment la salinité et la turbidité, expliquaient en grande partie la variabilité de la diversité de la population marine de Synechococcus des eaux côtières de Hong Kong. De plus, les changements temporels de l'abondance de Synechococcus découlaient largement de la température de l'eau.

Mots-clés : Synechococcus, diversité phylogénique, Hong Kong, espaceur intergénique transcrit de l’ADNr 16S-23S.

[Traduit par la Rédaction]

\section{Introduction}

Phototrophic picoplankton $(<3 \mu \mathrm{m})$ play an important role in the microbial food web and in primary production in the oceans (Li et al. 1983; Platt et al. 1983; Campbell et al. 1994; Liu et al. 2004b), and more recently, they have played an important role in river-impacted coastal waters, such as the Mississippi River plume (Liu et al. 2004a). Among different types of picoplankton, Synechococcus, small $(0.8 \sim 2 \mu \mathrm{m})$ unicellular cyanobacteria, is a major component that contains diverse ecotypes and phylotypes, ranging from coastal estuarine to oligotrophic open ocean strains (Water- bury et al. 1986; Urbach et al. 1998; Rocap et al. 2002; Scanlan and West 2002; Chen et al. 2004). Ubiquitous Synechococcus generally contain both red-pigmented phycoerythrin (PE)-rich strains and blue-green phycocyanin (PC)-rich strains. The former are the dominant forms in oceanic waters (Platt et al. 1983; Campbell and Carpenter 1987; Olson et al. 1990), whereas the latter are mainly found in turbid estuarine and coastal waters (Murrell and Lores 2004; Stomp et al. 2007).

Marine Synechococcus have been divided into 3 different clusters: marine cluster A (MC-A), marine cluster B (MC$\mathrm{B})$, and marine cluster $\mathrm{C}$ (MC-C), according to pigment con-

Received 13 August 2008. Revision received 25 October 2008. Accepted 10 November 2008. Published on the NRC Research Press Web site at cjm.nrc.ca on 30 March 2009.

H. Jing, R. Zhang, and P. Qian. Department of Biology, The Hong Kong University of Science and Technology, Clear Water Bay, Kowloon, Hong Kong SAR, China.

S.B. Pointing. Department of Ecology and Biodiversity, The University of Hong Kong, Pokfulam Road, Hong Kong SAR, China.

H. Liu. ${ }^{1}$ Department of Biology, The Hong Kong University of Science and Technology, Clear Water Bay, Kowloon, Hong Kong SAR, China; Atmospheric, Marine and Coastal Environment (AMCE) Program, The Hong Kong University of Science and Technology, Clear Water Bay, Kowloon, Hong Kong SAR, China.

${ }^{1}$ Corresponding author (e-mail: liuhb@ust.hk). 
Table 1. Biogeochemical properties of the surface water collected at Tung Lung Chau (TLC, $\left.22^{\circ} 14.9^{\prime} \mathrm{N}, 114^{\circ} 16.0^{\prime} \mathrm{E}\right)$, Hong Kong, in dif-

\begin{tabular}{llllllll}
\hline $\begin{array}{l}\text { Sampling } \\
\text { period }\end{array}$ & $T\left({ }^{\circ} \mathrm{C}\right)$ & Salinity & $\begin{array}{l}\text { Turbidity } \\
(\mathrm{NTU})\end{array}$ & $\begin{array}{l}\mathrm{DO} \\
(\mathrm{mg} / \mathrm{L})\end{array}$ & $\begin{array}{l}\mathrm{NH}_{4} \\
(\mu \mathrm{mol} / \mathrm{L})\end{array}$ & $\begin{array}{l}\mathrm{NO}_{3}+\mathrm{NO}_{2} \\
(\mu \mathrm{mol} / \mathrm{L})\end{array}$ & \begin{tabular}{l}
$\mathrm{TP}(\mu \mathrm{mol} / \mathrm{L})$ \\
\hline June 2004
\end{tabular} \\
Aug. 2004 & 27.1 & 32.0 & 7.4 & 6.8 & 8.57 & 3.64 & 0.97 \\
Oct. 2004 & 26.6 & 32.4 & 6.8 & 6.1 & 1.71 & 0.28 & 0.65 \\
Dec. 2004 & 20.0 & 33.3 & 8.6 & 6.7 & 1.93 & 1.21 & 0.65 \\
Feb. 2005 & 16.7 & 33.8 & 13.9 & 7.6 & 0.64 & 4.33 & 0.65 \\
Apr. 2005 & 21.3 & 32.8 & 6.8 & 9.0 & 3.57 & 6.64 & 0.65 \\
\hline
\end{tabular}

Note: $T$, temperature; NTU, nephelometric turbidity units; TP, total phosphorus; DO, dissolved oxygen; OTU, operational taxonomic unit; Chla, chloro-

tent and other physiological characterizations (Waterbury and Rippka 1989). However, most studies of cyanobacterial diversity by far were conducted on Synechococcus living in the offshore regions (Scanlan and West 2002). For estuaries and coastal ecosystems, research mostly has been limited to those in the temperate region (e.g., Geiss et al. 2004; Chen et al. 2006; Ahlgren and Rocap 2006). Little is known about the phylogenetic composition of Synechococcus populations in subtropical coastal systems, especially areas influenced by large rivers.

Previous studies of microbial diversity typically used the most conserved 16S rRNA gene (Fuller et al. 2003), which could not provide enough resolution for the subspecies level. The structure and length of the intergenic transcribed spacer (ITS) region between the highly conservative $16 \mathrm{~S}-23 \mathrm{~S}$ rRNA genes is inherently variable among microorganisms and is an ideal target region for discrimination of fine-scale relationships between closely related phylogenetic clusters (Fuller et al. 2003). The clone library encompassing the ITS rRNA gene allows the investigation of the diversity of various marine Synechococcus strains with high resolution (Rocap et al. 2002; Chen et al. 2006).

In this study, by using the clone library based on the ITS region and DNA fingerprinting techniques (restriction fragment length polymorphism; RFLP), we investigated the community composition of marine Synechococcus strains in a subtropical coastal water east of Hong Kong and compared their phylogenetic relationships with those occurring in other marine environments reported so far. Hong Kong's coastal environment is profoundly influenced by several different water masses, including freshwater discharge from the Pearl River, oceanic waters from the South China Sea, and coastal waters from the Zhejiang-Fujian Coastal Current (Dong et al. 2004). The dynamics of these water masses are also strongly influenced by the seasonal monsoon.

\section{Materials and methods}

\section{Sample collection}

Surface seawater samples $(<1 \mathrm{~m})$ were collected using Niskin bottles from Tung Lung Chau (TLC; $22^{\circ} 14.9^{\prime} \mathrm{N}$, $114^{\circ} 16.0^{\prime}$ E), Hong Kong, from June 2004 to April 2005. This station is one of the long-term environmental monitoring stations operated by the Hong Kong SAR government. About $500 \mathrm{~mL}$ of each water sample was filtered on board through a $0.22 \mu \mathrm{m}$ pore size membrane (47 $\mathrm{mm}$ in diameter, Millipore) with triplicates for each sample. The membranes were immersed in $0.8 \mathrm{~mL}$ of extraction buffer (Harder et al. 2003) and stored on dry ice until DNA extraction. Hydrographic and water chemistry data, including temperature, salinity, dissolved oxygen content, suspended solids, turbidity, macronutrients $(\mathrm{N}$ and $\mathrm{P}$,) and chlorophyll $a(\mathrm{Chl} a)$ concentrations, were obtained from the Environmental Protection Department of the Hong Kong SAR government (available from http://www.epd.gov. $\mathrm{hk} /$ ). Synechococcus enumeration was carried out with a Coulter Epics XL benchtop flow cytometer equipped with an air-cooled $15 \mathrm{~mW} 488 \mathrm{~nm}$ laser (Olson et al. 1993) and analyzed with CYTOWIN software (Vaulot 1989).

\section{DNA isolation and amplification}

Total genomic DNAs were extracted from filters and purified using proteinase $\mathrm{K}$ and sodium dodecyl sulfate concomitant with chloroform extraction and isopropanol precipitation, following the protocol described in Harder et al. (2003). Amplification of $1.5 \mathrm{~kb}$ of ITS regions from genomic DNAs were carried out by using primers that covered the distal and proximal conserved flanking regions of the $16 \mathrm{~S}$ rRNA gene, the ITS region, and the $23 \mathrm{~S}$ rRNA gene: the $16 \mathrm{~S}-1247$ specific forward primer (5'-CGTACTACAATGCTACGG-3') (Rocap et al. 2002) and the 23S-495 universal reverse primer $\left(5^{\prime}\right.$ ACGGTTTCAGGTTCTATTTCA TC-3') (this study). The reverse primer was designed based on a highly conservative region on the bacterial $23 \mathrm{~S}$ rRNA gene. Fifty microlitres of PCR reaction mixture contained $5 \mu \mathrm{L}$ of $10 \times$ buffer, $2 \mu \mathrm{L}$ of $\mathrm{MgCl}_{2}(25 \mathrm{mmol} / \mathrm{L}), 4 \mu \mathrm{L}$ of dNTPs $(2.5 \mathrm{mmol} / \mathrm{L}), 0.2 \mu \mathrm{L}$ of Taq polymerase $(5 \mathrm{U})$, and $1 \mu \mathrm{L}$ of each primer $(10 \mu \mathrm{mol} / \mathrm{L})$ and the following amplification programme was used: $95{ }^{\circ} \mathrm{C}$ for $3 \mathrm{~min}$; 30 cycles of $95{ }^{\circ} \mathrm{C}$ for $1 \mathrm{~min}, 55^{\circ} \mathrm{C}$ for $50 \mathrm{~s}, 72{ }^{\circ} \mathrm{C}$ for $1 \mathrm{~min}$; and a final extension at $72{ }^{\circ} \mathrm{C}$ for $10 \mathrm{~min}$. Amplicons were stained with ethdium bromide and visualized on $1 \%$ agarose gel.

\section{Clone library construction and RFLP screening}

PCR products were purified using the PureLink Quick Gel extraction kit (Invitrogen) and then cloned into the PCR4.0 vector by using the TOPO TA cloning kit (Invitrogen). Aproximately 80 colonies were randomly picked from each clone library. Colonies with correct insertions were digested by 3 restriction enzymes, EcoRI (G $\downarrow$ AATTC), HaeIII (GG $\downarrow \mathrm{CC}$ ), and HindIII(A $\downarrow$ AGCTT), at $37{ }^{\circ} \mathrm{C}$ for $3 \mathrm{~h}$ in $10 \times$ buffer $M$ (Amersham Biosciences). The restriction fragment banding patterns were visualized under UV light using a Universal Hood digital imaging system (Bio-Rad Laboratories) and were normalized against the $1 \mathrm{~Kb}$ Plus DNA ladder (Invitrogen). 
ferent seasons.

\begin{tabular}{lllllll}
\hline $\begin{array}{l}\text { Chla } \\
(\mu \mathrm{g} / \mathrm{L})\end{array}$ & $\begin{array}{l}\text { No. of Synechococcus } \\
\left(\times 10^{4} / \mathrm{mL}\right)\end{array}$ & $\begin{array}{l}\text { Total } \\
\text { OTUs }\end{array}$ & $\begin{array}{l}\text { Unique } \\
\text { OTUs }\end{array}$ & $\begin{array}{l}\text { Clones } \\
\text { analyzed }\end{array}$ & $\begin{array}{l}\text { Shannon-Weaver } \\
\text { index }\left(H^{\prime}\right)\end{array}$ & $\begin{array}{l}\text { Simpson's index of } \\
\text { diversity }(1-D)\end{array}$ \\
\hline 1.3 & 5.36 & 11 & 5 & 71 & 1.43 & 0.60 \\
1.6 & 12.37 & 10 & 5 & 75 & 1.33 & 0.62 \\
1.3 & 5.29 & 12 & 3 & 75 & 1.58 & 0.64 \\
1.6 & 1.20 & 12 & 6 & 74 & 1.64 & 0.69 \\
0.7 & 0.95 & 11 & 3 & 75 & 1.18 & 0.52 \\
0.9 & 1.34 & 13 & 5 & 75 & 1.44 & 0.59 \\
\hline
\end{tabular}

phyll $a$.

Fig. 1. Diversities and abundances of distinct restriction fragment length polymorphism (RFLP) patterns for the Synechococcus intergenic transcribed spacer (ITS) region and the ratios of phylotypes belonging to marine cluster A and marine cluster B in the 6 clone libraries constructed with water samples collected from Tung Lung Chau, Hong Kong, China. The code for each RFLP pattern refers to the representative clone being picked and sequenced.

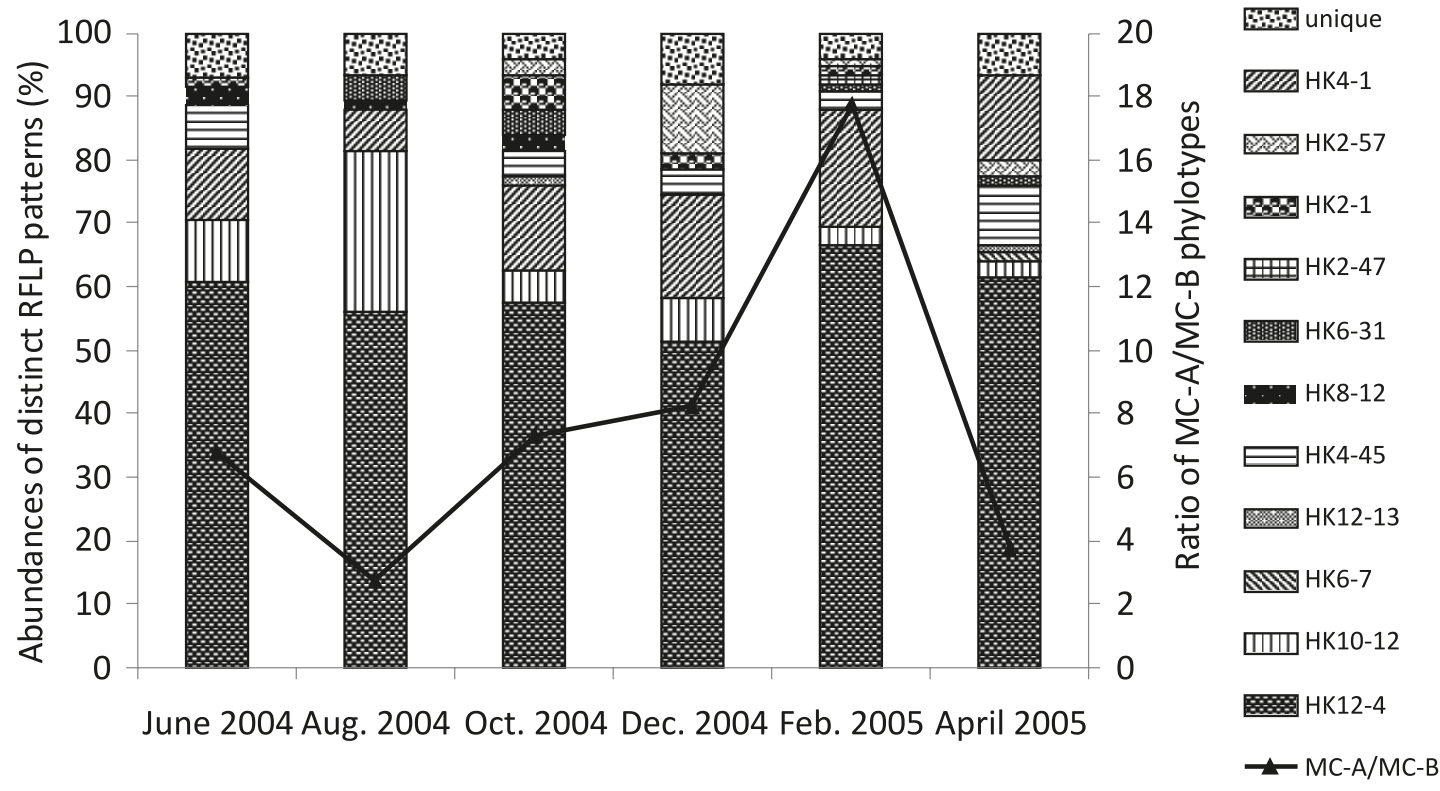

Fig. 2. Rarefaction curve calculated for the 6 clone libraries constructed with water samples collected from Tung Lung Chau, Hong Kong, China.

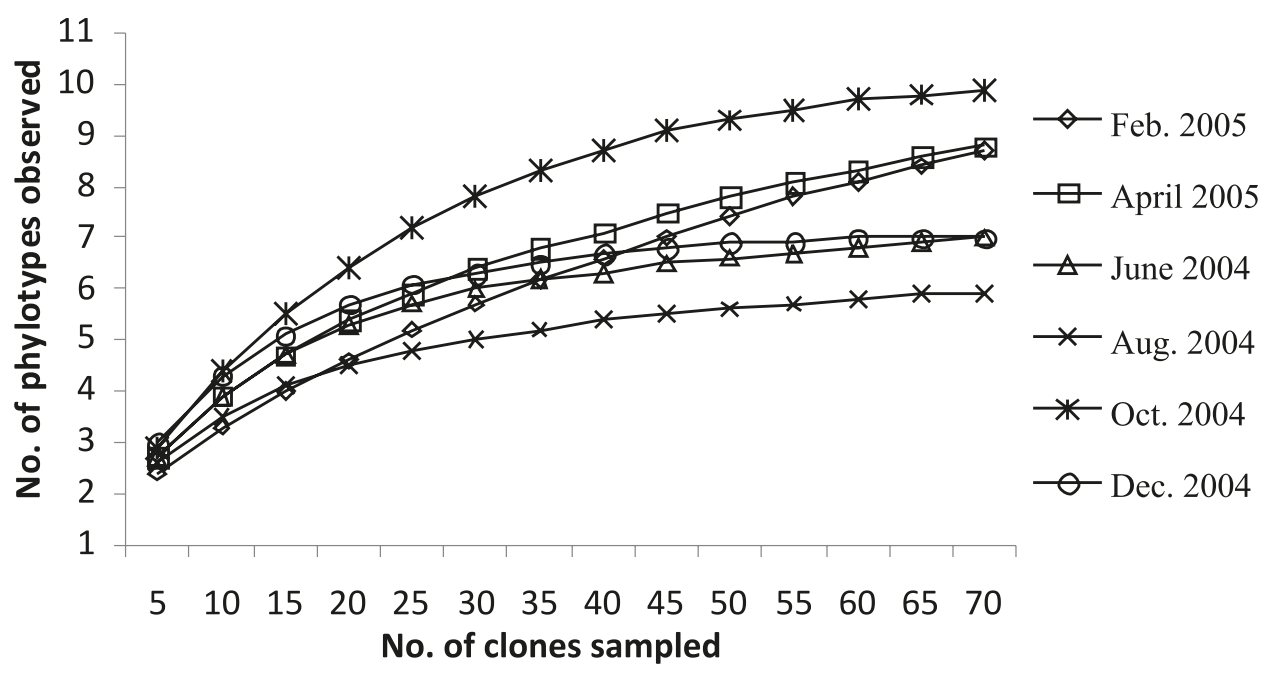


Fig. 3. Phylogenetic relationships among marine Synechococcus spp. based on neighbor-joining analysis of intergenic transcribed spacer (ITS) sequence data (690 positions). Sequence codes in bold were derived from this study and their GenBank accession Nos. are given in parentheses. Numeric suffixes denote different seasons that the sequences were collected. The scale bar represents 0.01 nucleotide changes per position.

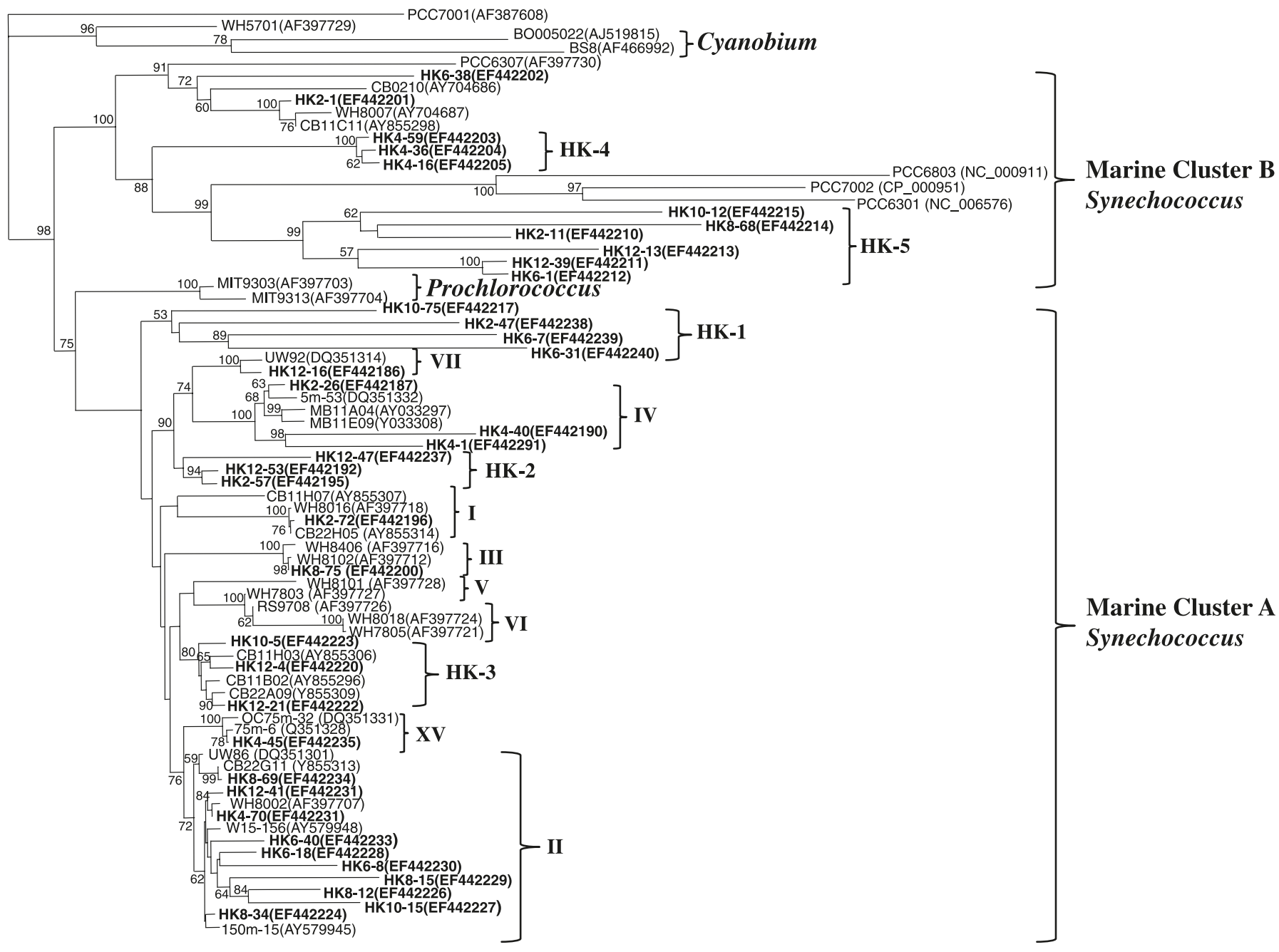

0.01

\section{Sequencing and phylogenetic analysis}

For groups of colonies showing the same RFLP pattern, 1 representative clone was randomly chosen. Plasmid DNAs of all colonies showing distinct RFLP fingerprints were extracted, purified, and then sequenced by a 3730 DNA analyzer (Applied Biosystems) using the BigDye Terminator Cycle sequencing kit version 3.1 (Applied Biosystems) with the QM13 forward primer.

BLAST searches of the GenBank database (available from http://www.ncbi.nlm.nih.gov) were performed for all sequences to determine their approximate phylogenetic affiliations. Neighbor-joining (NJ) trees for all sequences and their sister sequences downloaded from GenBank were generated withthe Phylip 3.67 program (http://evolution.genetics. washington.edu/Phylip.html) after alignment using ClustalX 1.80. Bootstrap values were obtained with 1000 resamplings and clades with greater than $50 \%$ bootstrap value were considered to be confident and shown on the nodes of branches.

\section{Diversity analysis}

Genetic diversity obtained was subjected to statistical analysis including (1) the total clone numbers analyzed; (2) the number of different operational taxonomic units (OTUs); (3) the Shannon-Weaver index $\left(H^{\prime}\right)$ and Simpson's index of diversity $(1-D)$. In addition, rarefaction curves as a measure of the coverage were plotted for each clone library using Analytic Rarefaction version 1.3 software (http://www.uga.edu/ $\sim$ strata/software) for a relative estimation of how well the subsample represented the environment. Principal component analysis (PCA) was conducted using JMP 4 software to test the relationship between Synechococcus phylogenetic diversity and environmental parameters.

\section{Nucleotide sequence accession Nos.}

ITS sequences of all colonies obtained from this study were deposited in the National Center for Biotechnology Information (NCBI) GenBank under accession Nos. EF442186-EF442241. 
Fig. 4. Principal component analysis plot based on the environmental variables measured from Tung Lung Chau, Hong Kong, China, at different sampling times (values listed in Table 1).

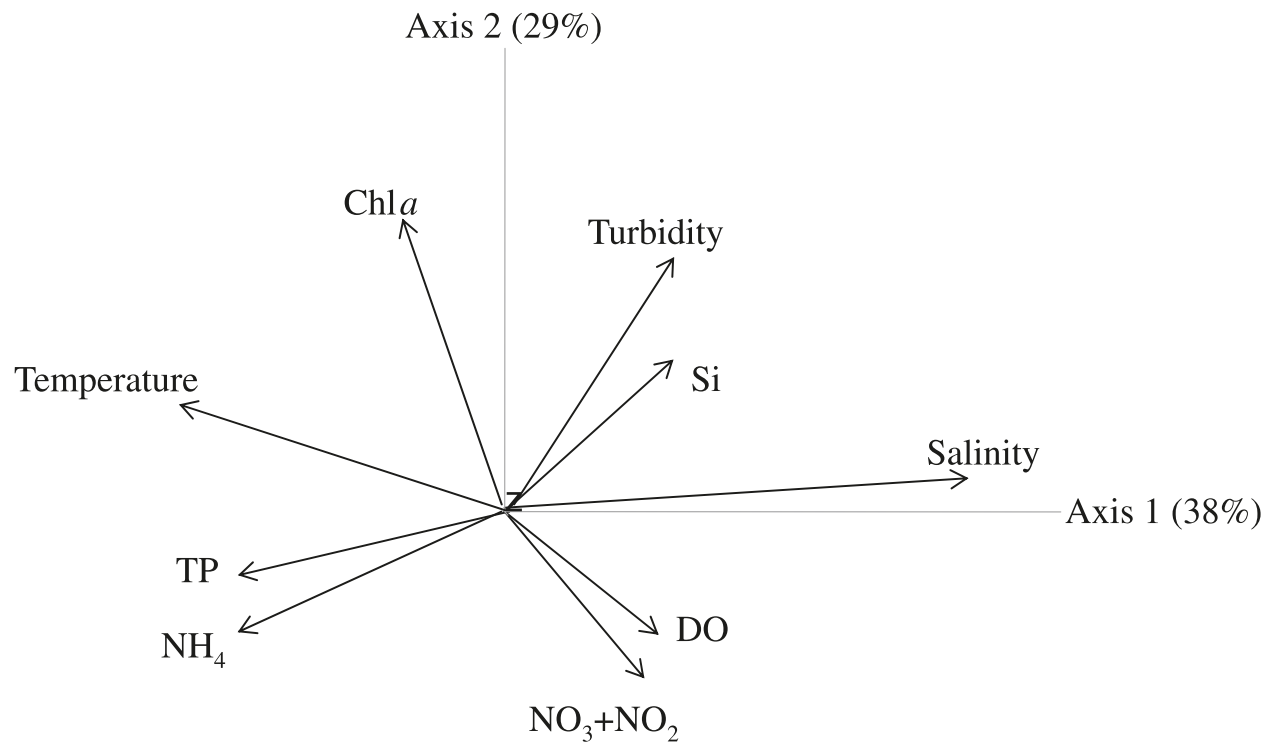

\section{Results}

\section{Hydrographical characterization}

The surface water temperature and salinity in different sampling months ranged from 16.7 to $27.2{ }^{\circ} \mathrm{C}$ and from 32 to $34.2 \mathrm{psu}$, respectively (Table 1). The highest $\left(27.2^{\circ} \mathrm{C}\right)$ and lowest $\left(16.7^{\circ} \mathrm{C}\right)$ surface water temperatures were observed in August and February, respectively. Macronutrients $(\mathrm{N}$ and $\mathrm{P}$ ) were all relatively high, indicating no nutrient limitation to the growth of Synechococcus. Additionally, significantly high concentrations of suspended solids, and hence the highest turbidity, was found in the surface water in December. Chl $a$ concentrations ranged from 0.7 to $1.6 \mu \mathrm{g} / \mathrm{L}$, with the lowest occurring in February, coincident with the lowest temperature. In contrast to the relatively small variation range of Chla, Synechococcus abundance fluctuated $>10$ times throughout the year, with a clear peak in summer (Table 1).

\section{ITS gene clone libraries and statistical analysis}

The diversity and abundance of the ITS regions were highly variable in each clone library as indicated by RFLP patterns, reflecting distinct Synechococcus species composition (Fig. 1). In total, 445 positive ITS clones were derived and 38 distinct ITS RFLP patterns were obtained after RFLP screening. Among them, 27 RFLP patterns were only found in 1 sample and another 11 patterns were found in $>1$ sample. The name of the representative colony from each distinct RFLP pattern was used to denote the corresponding RFLP pattern. The number of unique RFLP patterns occurring in each clone library was quite different, with 6 for December $(50 \%$ in total patterns, $8.1 \%$ in total clones) and only 3 for October (25\% in total patterns, $4 \%$ in total clones) and February (27.3\% in total patterns, $4 \%$ in total clones). Within the 11 patterns showing more than once, 3 of them, HK10-12, HK6-7 and HK12-4, presented in all clone libraries, and HK12-4 was the most dominant clone, accounting for more than half of the total clone population in each library (Fig. 1). In addition, HK4-45 was present in all screenings except August. The other 7 RFLP patterns, HK6-31, HK8-12, HK12-13, HK2-1, HK2-47, HK2-57, and HK4-1, only occurred in specific months.

Overall, the highest and lowest diversity in the whole sampling period estimated from the Shannon-Weaver index and Simpson's diversity index occurred in December and February samples, respectively (Table 1). Furthermore, the rarefaction curves start to become relatively flat when $>45$ colonies were picked (Fig. 2), meaning that the clone numbers screened in each library were statistically sufficient for diversity analysis.

\section{Phylogeny and variation of the Synechococcus population}

Phylogenetic analysis revealed that all the new phylotypes recovered from Hong Kong coastal waters were Synechococcus and affiliated with either Synechococcus MC-A or MC$\mathrm{B}$, and the abundance of phylotypes belonging to the former cluster was far greater than the latter in each ITS clone library (Fig. 1). The highest number of MC-A and the lowest number of MC-B phylotypes were found in February samples, whereas the opposite pattern was observed in the $\mathrm{Au}-$ gust samples. The remarkable increase in abundance of MC-B phylotype HK10-12 in August and MC-A phylotypes HK124 and HK6-7 in February, caused the variation in the ratio of the numbers of $\mathrm{MC}-\mathrm{B}$ phylotypes to MC-A phylotypes.

In the phylogenetic tree, 27 out of the 38 distinct Synechococcus phylotypes clustered within MC-A and 11 clustered within MC-B (Fig. 3). Most MC-A phylotypes fell within 8 known Synechococcus subclusters (Fuller et al. 2003), but 2 new subclusters, HK-1 and HK-2, were also formed. These 2 subclusters were exclusively comprised of Synechococcus phylotypes obtained from this study, representing unique Synechococcus spp. in Hong Kong coastal waters. Additionally, subcluster HK-3 contained closely related Synechococcus from both Hong Kong coastal water and Chesapeake Bay (Chen et al. 2006). MC-B are comprised of 2 distinct Synechococcus subclusters. Phylotypes 
HK2-1 and HK6-38 are closely related to strains isolated from Chesapeake Bay (Chen et al. 2006) and Woods Hole (Rippka et al. 1979). Two distinct clades, HK-4 and HK-5, exclusively contained strains from Hong Kong coastal waters, and grouped together with both freshwater (PCC6803, PCC6301) and marine (PCC7002) Synechococcus strains (Rippka et al. 1979; Waterbury and Rippka 1989).

PCA demonstrated that the first and second principal components accounted for $67 \%$ of the total variance (Fig. 4). In the PCA analysis, longer arrows indicated a greater variation; arrows with narrow angles were strongly correlated; arrows that were perpendicular showed no correlation; and arrows in opposite directions indicated negative correlation. The positive values and the longer arrow showed that salinity and turbidity were positively correlated to the first 2 principal components and could be the possible controlling factors for Synechococcus diversity. The total operational taxonomic units (OTUs) in each clone library were positively correlated with salinity $(R=0.874, p<$ $0.05)$.

\section{Discussion}

Phylogenetic data from this study revealed that strains of Synechococcus in both MC-A and MC-B were abundant in Hong Kong coastal waters, but no Prochlorococcus and $C y$ anobium phylotypes were detected by the ITS primers, although the forward primer was supposed to delineate closely related strains of Prochlorococcus, Synechococcus, and Cyanobium (Rocap et al. 2002).

In agreement with previous studies (Wood 1985; Ahlgren and Rocap 2006), most of our marine Synechococcus phylotypes belong to MC-A. Within this cluster, 10 phylotypes from our study belonged to the low phycourobilin (PUB) clade II, which usually dominates in surface waters (Toledo and Palenik 2003); 1 phylotype belonged to the high-PUB clade III, which possesses mobility; and another one fell into clade $\mathrm{XV}$ and then further clustered with clade II. Clades XV and II are always closely related, and they are distinct from each other because of the special characteristic of chromatic adaptation in the former (Ahlgren and Rocap 2006). Interestingly, 3 specific MC-A clades were also found. Clade HK-2 and HK-1 exclusively contained 3 Hong Kong marine Synechococcus phylotypes and formed a subclade within clades IV and VII. Clade HK-3 included phylotypes detected in Hong Kong coastal waters and Chesapeake Bay, and then clustered with clades V and VI, which contained strains with low PUB/PEB ratios and strains containing no PUB, respectively (Rocap et al. 2002).

In contrast, less diversity was found in the MC-B cluster in terms of the number of unique phylotypes and their phylogenetic distributions. Our MC-B phylotypes were distributed into 2 subclusters that contained both freshwater and marine strains rich in PE or PC. In the second MC-B subcluster, phylotypes recovered from each sampling season were found and grouped with PC-containing and PE-lacking strains isolated from marine and freshwater environments (Rippka et al. 1979). In addition, clade HK-4 specific to the April samples was also recovered. Clades HK-4 and HK-5 were phylogenetically quite distinct from other sister phylo- types, therefore, they potentially represent a novel marine Synchococcus lineage within MC-B, although morphological and physiological characteristics of isolated cultures from Hong Kong coastal waters are needed for further elucidation.

Furthermore, the most abundant Synechococcus phylotype (HK12-4), which was present throughout the year, was closely related to the strains containing low or no PUB. The other 2 common phylotypes, HK6-7 and HK10-12, were members of Hong Kong local Synechococcus clades, clade HK-4 of MC-B and clade HK-1 of MC-A, respectively. This finding is in agreement with the well-established view that Synechococcus containing no or low PUB occurs only in coastal waters, whereas high-PUB strains are the predominant forms of marine Synechococcus in the open ocean (Olson et al. 1990; Wood et al. 1998).

Environmental factors, such as temperature, light, nutrient concentrations, and vertical mixing, have been assumed to be strong selective factors affecting the dynamics and distribution of Synechococcus populations (Wyman et al. 1985). Nutrient depletion causing seasonal changes of Synechococcus morphotypes had been observed previously (Weisse and Kenter 1991). In our study, relatively high concentrations of inorganic nutrients throughout the year indicate no serious nutrient limitation on Synechococcus growth. Based on the PCA plots, salinity and turbidity appeared to be the most important factors affecting the diversity of Synechococcus spp. in Hong Kong coastal waters. The highest diversity of Synechococcus populations in December was likely the result of intrusion of the Zhejiang-Fujian Coastal Current, increased vertical mixing, and coastal downwelling, all because of the prevailing northeast monsoon (Chiu et al. 1985), as indicated by relatively high salinity and a high water column turbidity (Table 1). As the temperature dropped to its lowest, a sharp drop in the Chla concentration, Synechococcus abundance, and total Synechococcus diversity occurred in February. In addition, temperature has been frequently reported as the most important environmental factor affecting the growth of Synechococcus (Agawin et al. 1998, 2000). In our study, Synechococcus abundance was significantly correlated to sea surface temperature $(R=$ 0.79), suggesting that the seasonal variation of Synechococcus abundance was regulated by water temperature.

The fact that MC-A species dominated throughout the year suggests that the area is strongly influenced by the offshore water of the South China Sea. During summer the sampling area was affected by the Pearl River plume through the South China Sea Current when the southwest monsoon prevailed (Chiu et al. 1985). High temperature and heavy rainfall could also enhance the stratification of the water column, resulting in the increase of MC-B Synechococcus in the surface waters. On the other hand, in fall and winter, the sampling site was influenced by the intrusion of both the Zhejiang-Fujian Coastal Current and the oceanic water from the South China Sea because of the strong northeast monsoon, resulting in low abundance of MC-B phylotypes.

Our study provides insights into the phylogenetic composition and variation of Synechococcus in subtropical coastal water. Results from this study demonstrate high phylogenetic diversity of both MC-A and MC-B Synechococcus in 
Hong Kong coastal waters, and the seasonal variation of Synechococcus composition could be the result of the dynamics and mixing of different water masses in the study sites, which is modulated by monsoonal winds. Because there are only a very small number of studies using the Synechococcus ITS region (Rocap et al. 2002; Brown et al. 2005; Ahlgren and Rocap 2006; Chen et al. 2006), and most of these studies were conducted in marine environments that were geographically distant and hydrographically distinct from our study site, it is inappropriate to make a direct comparison. Morphological and physiological characterization of isolated strains will provide useful information for Synechococcus diversity under various aquatic conditions.

\section{Acknowledgements}

This research is supported by a Hong Kong RGC grant to H.L. (HKUST6414/06M).

\section{References}

Agawin, N.S.R., Duarte, C.M., and Agusti, S. 1998. Growth and abundance of Synechococcus sp. in a Mediterranean bay: seasonality and relationship with temperature. Mar. Ecol. Prog. Ser. 170: 45-53. doi:10.3354/meps170045.

Agawin, N.S.R., Duarte, C.M., and Agusti, S. 2000. Nutrient and temperature control of the contribution of picoplankton to phytoplankton biomass and production. Limnol. Oceanogr. 45: 591600.

Ahlgren, N.A., and Rocap, G. 2006. Culture isolation and cultureindependent clone libraries reveal new marine Synechococcus ecotypes with distinctive light and $\mathrm{N}$ physiologies. Appl. Environ. Microbiol. 72: 7193-7204. doi:10.1128/AEM.0035806. PMID: 16936060.

Brown, M.V., Schwalbach, M.S., Hewson, L., and Fuhrman, J.A. 2005. Coupling 16S-ITS rDNA clone libraries and automated ribosomal intergenic spacer analysis to show marine microbial diversity: development and application to a time series. Environ. Microbiol. 7: 1466-1479. doi:10.1111/j.1462-2920.2005.00835. x. PMID:16104869.

Campbell, L., and Carpenter, E.J. 1987. Characterization of phycoerythrin-containing Synechococcus spp. populations by immunofluorescence. J. Plankton Res. 9: 1167-1181. doi:10.1093/ plankt/9.6.1167.

Campbell, L., Nolla, H.A., and Vaulot, D. 1994. The importance of Prochlorococcus to community structure in the central North Pacific Ocean. Limnol. Oceanogr. 39: 954-961.

Chen, F., Wang, K., Kan, J., Bachoon, D.S., Lu, J., Lau, S., and Campbell, L. 2004. Phylogenetic diversity of Synechococcus in the Chesapeake Bay revealed by ribulose-1,5-bisphosphate carboxylase-oxygenase (RuBisCO) large subunit gene (rbcL) sequences. Aquat. Microb. Ecol. 36: 153-164. doi:10.3354/ ame036153.

Chen, F., Wang, K., Kan, J., Suzuki, M.T., and Wommack, K.E. 2006. Diverse and unique picocyanobacteria in Chesapeake Bay, revealed by $16 \mathrm{~S}-23 \mathrm{~S}$ rRNA internal transcribed spacer sequences. Appl. Environ. Microbiol. 72: 2239-2243. doi:10.1128/ AEM.72.3.2239-2243.2006. PMID:16517680.

Chiu, M.T.L., Chung, R.T., and Luk, R.W.K. 1985. Chemical hydrographic observations of the southern and eastern coastal waters of Hong Kong. Asian Mar. Biol. 2: 37-46.

Dong, L., Su, J., Wong, L.A., Cao, Z., and Chen, J.C. 2004. Seasonal variation and dynamics of the Pearl River plume. Cont. Shelf Res. 24: 1761-1777. doi:10.1016/j.csr.2004.06.006.
Fuller, N.J., Marie, M.D., Partensky, F., Vaulot, D., Post, A.F., and Scanlan, D.J. 2003. Clade-specific 16S ribosomal DNA oligonucleotides reveal the predominance of a single marine Synechococcus clade throughout a stratified water column in the Red Sea. Appl. Environ. Microbiol. 69: 2430-2443. doi:10.1128/ AEM.69.5.2430-2443.2003. PMID:12732508.

Geiss, U., Selig, U., Schumann, R., Steinbruch, R., Bastrop, R., Hagemann, M., and Schoor, A. 2004. Investigations on cyanobacterial diversity in a shallow estuary (Southern Baltic Sea) including genes relevant to salinity resistance and iron starvation acclimation. Environ. Microbiol. 6: 377-387. doi:10.1111/j. 1462-2920.2004.00569.x. PMID:15008815.

Harder, T., Lau, C.K.S., Dobretsov, S., Fang, T.K., and Qian, P.Y. 2003. A distinctive epibiotic bacterial community on the soft coral Dendronephthya sp., and antibacterial activity of coral tissue extracts suggest a chemical mechanism against bacterial epibiosis. FEMS Microbiol. Ecol. 43: 337-347. doi:10.1111/j.15746941.2003.tb01074.x.

Li, W.K.W., Subba Rao, D.V., Harrison, W.G., Smith, J.C.J., Cullen, J., Irwin, B., and Platt, T. 1983. Autotrophic picoplankton in the tropical ocean. Science, 219: 292-295. doi:10.1126/ science.219.4582.292. PMID:17798278.

Liu, H., Dagg, M.J., Campell, L., and Urban-Rich, J. 2004a. Picophytoplankton and bacterioplankton in the Mississipi River plume and adjacent waters in the Gulf of Mexico. Estuaries, 27: 147-156. doi:10.1007/BF02803568.

Liu, H., Suzuki, K., and Saito, H. 2004b. Community structure and dynamics of phytoplankton in the western subarctic pacific ocean — a synthesis. J. Oceanogr. 60: 119-137. doi:10.1023/ B:JOCE.0000038322.79644.36.

Murrell, M.C., and Lores, E.M. 2004. Phytoplankton and zooplankton seasonal dynamics in a subtropical estuary: importance of cyanobacteria. J. Plankton Res. 26: 371-382. doi:10.1093/ plankt/fbh038.

Olson, R.J., Chisholm, S.W., Zettler, E.R., and Armbrust, E.V. 1990. Pigment, size, and distribution of Synechococcus in the North Atlantic and Pacific Oceans. Limnol. Oceanogr. 35: 45-58.

Olson, R.J., Zettle, R.E.R., and DuRand, M.D. 1993. Phytoplankton analysis using flow cytometry. In Handbook of methods in aquatic microbial ecology. Edited by P. Kemp. Lewis Publishers, Boca Raton, Florida. pp. 175-186.

Platt, T., Rao, D.V.S., and Irwin, B. 1983. Photosynthesis of picoplankton in the oligotrophic ocean. Nature, 301: 702-704. doi:10.1038/301702a0.

Rippka, R., Deruelles, J., Waterbury, J.B., Herdman, M., and Stainer, R.Y. 1979. Genetic assignments, strain histories, and properties of pure cultures of cyanobacteria. J. Gen. Microbiol. 111: $1-61$.

Rocap, G., Distel, D.L., Waterbury, J.B., and Chisholm, S.W. 2002. Resolution of Prochlorococcus and Synechococcus ecotypes by using 16S-23S ribosomal DNA internal transcribed spacer sequences. Appl. Environ. Microbiol. 68: 1180-1191. doi:10. 1128/AEM.68.3.1180-1191.2002. PMID:11872466.

Scanlan, D.J., and West, N.J. 2002. Molecular ecology of the marine cyanobacterial genera Prochlorococcus and Synechococcus. FEMS Microbiol. Ecol. 40: 1-12. doi:10.1111/j.1574-6941. 2002.tb00930.x.

Stomp, M., Huisman, J., Vörös, L., Pick, F.R., Laamanen, M., Haverkamp, T., and Stal, L.J. 2007. Colourful coexistence of red and green picocyanobacteria in lakes and seas. Ecol. Lett. 10: 290-298. doi:10.1111/j.1461-0248.2007.01026.x. PMID:17355568.

Toledo, G., and Palenik, B. 2003. A Synechococcus serotype is found preferentially in surface marine water. Limnol. Oceanogr. 48: $1744-1755$. 
Urbach, E., Scanlan, D.J., Distel, D.L., Waterbury, J.B., and Chisholm, S.W. 1998. Rapid diversification of marine picophytoplankton with dissimilar light harvesting structures inferred from sequences of Prochlorococcus and Synechococcus (Cyanobacteria). J. Mol. Evol. 46: 188-201. doi:10.1007/PL00006294. PMID:9452521.

Vaulot, D. 1989. CYTOPC: processing software for flow cytometric data. Signal and Noise, 2: 8-8.

Waterbury, J.B., and Rippka, R. 1989. The order Chroocococales. In Bergey's manual of systematic bacteriology. Edited by N.R. Krieg and J.B. Holt. Vol. 3. Williams \& Wilkins, Baltimore, Maryland. pp. 1728-1746.

Waterbury, J.B., Watson, S.W., Valois, F.W., and Franks, D.G. 1986. Biological and ecological characterization of the marine unicellular cyanobacterium Synechococcus. Can. Bull. Fish. Aquat. Sci. 214: 71-120.
Weisse, T., and Kenter, U. 1991. Ecological characteristics of autotrophic picoplankton in a prealpine lake. Int. Rev. Ges. Hygrobiol. 76: 493-504. doi:10.1002/iroh.19910760403.

Wood, A.M. 1985. Photosynthetic apparatus of marine ultraphytoplankton adapted to nature light fields. Nature, 316: 253-254. doi: $10.1038 / 316253 \mathrm{a} 0$.

Wood, A.M., Phinney, D.A., and Yentsch, C.S. 1998. Water column transparency and the distribution of spectrally distinct forms of phycoerythrin-containing organisms. Mar. Ecol. Prog. Ser. 162: 25-31. doi:10.3354/meps162025.

Wyman, M., Gregory, R.P.F., and Carr, N.G. 1985. Novel role for phycoerythrin in marine cyanobacterium, Synechococcus strain DC2. Science, 230: 818-820. doi:10.1126/science.230.4727.818. PMID:17791796. 
Copyright of Canadian Journal of Microbiology is the property of NRC Research Press and its content may not be copied or emailed to multiple sites or posted to a listserv without the copyright holder's express written permission. However, users may print, download, or email articles for individual use. 